\title{
Improving parent competences in promoting literacy development - some results of a pilot study
}

\author{
Agnes Nyitrai ${ }^{1}$, Judit Podráczky ${ }^{1 \mathrm{a}}$ \\ ${ }^{1}$ Kaposvár Universíty, Faculty of Pedagogy, Guba S. str. 40. Kaposvár 7400, Hungary
}

\begin{abstract}
It is obvious by now that promoting emergent literacy development is one of the most important means of addressing disadvantages. This does not only mean a more sophisticated reflection on methodology issues in early childhood and pre-school education but also includes designing programmes which are suitable for promoting parent competences, which could be regarded as a target of development work and also as the guiding principle of our own work.
\end{abstract}

Keywords: emergent literacy; storytelling; early childhood education; preschool education; parental involvement; parent competences

\section{Introduction}

\subsection{SIGNALS-project - framework of our study}

Our study is implemented within the framework of the "SIGNALS" Strengthening Activity-Oriented Interaction and Growth in the Early Years and Transitions project within the COMENIUS sub-programmes of the EU Lifelong-Learning Programme, and it is coordinated by the University of Cologne in the period between 01/01/2014 and 31/12/2015 with the participation of seven countries (Germany, Denmark, Greece, Hungary, Island, Romania and Sweden). The Hungarian consortium-partner is the General Directorate of Social Affairs and Child Protection, with the Kaposvár University taking part in the realisation of the project.

The main targets of the EU project are the following:

1)Supporting early-childhood pedagogues, kindergarten-pedagogues, primary school teachers and parents in building positive child-adult relationship that will enhance development;

\footnotetext{
${ }^{a}$ Corresponding author: nyitrai.agnes4@gmail.com
} 
2)Strengthening early-childhood pedagogues, kindergarten-pedagogues, primary school teachers (1-8 years of age) and parents' communicative competences;

3)Presenting "Exemplary Co-operative Educational Practices" among all actors.

The targets of the Kaposvár University are:

1) To design methodological programmes for early childhood pedagogues and kindergarten pedagogues for developing a) their own competences for supporting literacy development of children; b) parents' competences which enhance literacy competences.

\subsection{Theoretical background of the pilot study}

Emergent literacy [18] means "growing into" written culture in preschool period with 1) storytelling and picture book reading; 2) imitating writing and reading in play; and 3) experiences in daily activities with parents and with pedagogues.

Storytelling and picture book reading experiences are playing a key role at an early age, and parent-child interaction, which supports pre-school age literacy development, is of utmost importance in early-childhood and pre-school education, [16, 10, 2, 3, and 17]. Children's family literacy environment varies significantly; while some children have regular experiences in listening to tales or stories and looking at story books at home, others come across this experience in the nursery or in the pre-school for the first time. One of the major determining factors in these differences is parents' qualifications, [16, 12, and 14]. It has been known from research results for decades that children whose parents regularly tell them tales and stories exceed their peers who are lacking this experience by approximately 1.5 years in development, [9, 4]. The different socio-cultural situations of families imply significant differences in the literary environment surrounding children, and the compensation of related disadvantages is an essential task of institutional education $[1,18$, and 13].

There have been significant changes in recent decades regarding attitudes to cooperation with parents in terms of both content and methodology, $[6,5]$. As a result of these changes, improving parental involvement has become a major target at international level and it has been more and more emphasised in the educational policies of developed countries. There are a number of initiatives among the EU recommendations encouraging the strengthening of the institutional relationship with parents, promoting parental involvement and developing parents' competences. Our research results from Hungary show that although steps have been taken to form partnerships, there are no significant results yet: teachers often think that parents are not interested enough while parents think teachers do not give them enough feedback and help, [8, 7 and15]. According to our experiences parents' involvement and their willingness to be involved depend on the children's age and the teacher's characteristics. Teachers and parents must rely more on each other at younger ages of children and this circumstance is more favourable for forming a partnership.

There are some works especially for supporting family literacy projects, for developing parents' competences in storytelling and picture book reading, [11].

\subsection{System of early childhood education in Hungary}

Introducing early childhood education system in Hungary is important in understanding our results and conclusions. There are two general types of preschool institutions for -children in Hungary: infant-toddler centers and kindergartens.

Infant-toddler centers are for 0-3 years-old children. These are not compulsory: only 14 $\%$ of the age group attend these centers (there are not enough places). There are 12-14 children per group. Early childhood pedagogues have usually post-secondary qualification, 
$10 \%$ of them have qualification at BA-level. (Their BA-level qualification was accredited in 2008). Infant-toddler centers come under the regulation of social affairs, to the system of children's protection. (There have been infant-toddler centers in Hungary since 1852).

Kindergarten is the first stage of public education for 3-6 (7) years-old children. It has been compulsory to attend from the age of 5 for 22 years, but starting from 1st September 2015 it will be compulsory from the age of 3. There are 13-25 children per group. All kindergarten pedagogues have qualification at BA-level. (There have been kindergartens in Hungary since 1828).

\section{Aims, methods and sample of pilot study}

Our target is to design a programme aimed at improving parents' competences which enhance children's literacy development. Our research on which the programme will be based focuses partly on mapping early-childhood and kindergarten pedagogues' opinions of children's attitudes to tales, story books and media and of the factors influencing these as well as of their own roles, opportunities and co-operation with the parents. We made focusgroup and semi-structured individual interviews with 30 early-childhood pedagogues and 30 kindergarten pedagogues. (There are about 294 children in the involved infant-toddler centers and there are about 306 children in the involved kindergartens this year). The interview questions were related to the following:

1)Storytelling habits at home, trends and changes;

2)Children's attitudes to tales, storytelling, and books in infant-toddler centres and in kindergartens;

3)Supporting parents' involvement, possibilities for co-operation, promotion, mutual reflections regarding storytelling.

4)The place and the role of storytelling in the work of the educational staff. (Professional opinions on the role of tales. Preparation. Available professional literature to rely on. Further training and consultation opportunities. Success and difficulties. Cooperation with other members of staff).

As a by-product of the interviews, certain elements of the interviewed educators' parent-image were also shown and we regard these as a major determining factor of the relationship with parents and with children.

\section{Some results of pilot study}

\subsection{Storytelling in the families}

Usually, children watch TV instead of picture book reading or storytelling with parents at home. They are often alone in these situations, without their parents, so in most of these situations there isn't enough control and help to understand contents. Some children - e.g. a two-year old boy - have got their own tablets, etc. for watching cartoons. Sometimes early childhood pedagogues couldn't see any picture books in the families' home. The other problem is: a lot of parents read tales with the aim of developing children's skills, which means there are other points of views in choosing books, tales in these situations than in the situations of reading just for enjoying them. There are some positive experiences, too, e. $\mathrm{g}$. some of parents have old picture books from their own childhood, etc.

There is a great variation in storytelling in families of children attending kindergarten, too: storytelling takes place often, rarely or never in families. Books are rarely given to children as a present, and sometimes with the aim of supporting development, not only for enjoying them. There are some "trendy tales", first of all Disney-productions. The 
kindergarten pedagogues talked about the changes of parent-child communication, too, they thought, intimacy between parents and children isn't as important for parents as it was before.

\subsection{Children's attitudes to tales, storytelling and books in institutions}

The families - mainly mothers - have a strong influence on attitudes to storytelling of children: more storytelling at home result in better understanding of stories and tales in infant-toddler centers, too. Positive attitudes of children to storytelling have been emerging step by step; using books must be learnt, too. Puppets play important role in situations of storytelling for small children in helping to understand and to enjoy them.

Kindergarten children like storytelling, too, but they can listen to it less and less, because of watching a lot of films. They like picture book reading together with their pedagogue. They rarely bring books from home to the kindergarten. The pedagogues have positive experiences in visiting the library with children. Media-tales are often present during the play of children, pedagogues' opinion is not positive about it.

\subsection{Supporting parents' involvement}

According to early childhood pedagogues, what parents are mostly interested in is the text of nursery rhymes. Pedagogues usually recommend reading picture books, but they don't know whether the parents take their advice or not.

Kindergarten pedagogues have less positive experience with parents' involvement. They tried common storytelling to parents with their children but they have ambivalent experiences about it. They tried interactive storytelling with parents but it wasn't successful. There was drama play on parents evening, too. They had averse feelings first but their attitude improved later. Most of the parents talk to pedagogues only when there are problems with the development or the behavior of their children.

\subsection{The place and the role of storytelling in the work of the education staff}

Early childhood pedagogues feel unbacked in these situations, they are in need of professional support, but it is a complicated situation, e. g. they don't have enough money for further education. They propose to publish a collection of stories; a book written of "Storytelling in nursery" would be very useful.

Kindergarten pedagogues don't really know the contemporary literature for children, they have difficulties with it, and they don't really know the new cartoon films for children (it depends on how old their own children are). Pedagogues would like to have consultations with HUNRA (Hungarian Reading Society), too.

\subsection{Opinion of pedagogues about parents' habits of storytelling at home and about parents' involvement}

Analysis of the interviews shows negative tendencies of pedagogues' opinions about parents' competences and behaviour in situations of storytelling with their own children at home: out of 54 opinions of early childhood pedagogues there were only 22 positive; out of 52 opinions of kindergarten pedagogues there were only 7 positive. The early childhood pedagogues appreciate parents more than kindergarten pedagogues. Kindergarten pedagogues have more determined expectations toward parents and there is a strong nostalgia for the families of earlier decades in their hearts; they think parents had better 
attitudes to their children some years or decades ago. It is very interesting because nowadays parents are usually older than ever before.

Their opinion about the parents' involvement isn't really positive, either. The kindergarten pedagogues made more attempts to involve parents but have had less success in these cases.

\section{Conclusion, further tasks}

In the course of further research we would like to study pedagogues' image of parents. We consider this to be the major determining factor of the relationship with parents and children.

In the field of methodological development we would like to develop

1) a continuing educational project which could

-help to optimize the relationship with parents / families

- form attitudes towards parents

-focus on different methods to involve parents and concrete action plans

2) programmes for pedagogues to develop their own competences in supporting literacy development of children.

\section{References}

1. Bernstein, B., Nyelvi szocializáció és oktathatóság. In: Melegh, Cs. (szerk.): Iskola és

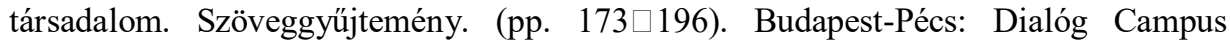
Kiadó, (1999).

2. Bus, A.G., Joint caregiver-child storybook reading: A route to literacy development. In: Neuman, S.B. és Dickinson, D.K. (Eds.): Handbook of early literacy research.(pp. 179 $\square$ 191). New York: The Guilford Press, (2002).

3. Cairney, T. H., Literacy within family life. In N. Hall, J. Larson, \& J. Marsh (Eds.), Handbook of early childhood literacy. (pp. 85 $\square 98$ ). London: SAGE, (2003).

4. Cs. Czachesz, E. Olvasás és nevelés az iskoláskor előtt. Könyv és Nevelés, 2001. 2. sz. http://www.opkm.hu/konyvesneveles/2001/2/cikk4.html. A megtekintés dátuma: 2007. 11. 07, (2001).

5. Desforges, C. \& Abouchaar, A., The impact of parental involvement, parental support and family education on pupil achievement adjustment: A literature review, Research Report 433. London: Department for Education and Skills, (2003).

6. Epstein, J. (2001): School, family, and community partnerships: Preparing educators and improving schools. Westview Press, Boulder, CO.

7. F. Lassú, Zs., Perlusz A. \& Marton E., Elvek és gyakorlatok. Példaértékü kezdeményezések Magyarországon a család és intézmény kapcsolatának, a szülök bevonódásának támogatására. In: Podráczky, J. (szerk.): Szövetségben. Tanulmányok a család és az intézményes nevelés kapcsolatáról. (pp. 85-102). Budapest: ELTE Eötvös Kiadó, (2012).

8. Hegedűs, J. \& Podráczky, J., Fókuszcsoportos beszélgetések a közoktatási intézmény és a család kapcsolatáról - első reflexiók a kutatás kapcsán. In: Podráczky, J. (szerk.): Szövetségben. Tanulmányok a család és az intézményes nevelés kapcsolatáról. (pp. 105-124). Budapest, ELTE Eötvös Kiadó, (2012).

9. Nagy, J., 5-6 éves gyermekeink iskolakészültsége. Budapest: Akadémiai Kiadó, (1980).

10. Nelson, K., Language in cognitive development. The emergence of the mediated mind. Cambridge: Cambridge University Press, (1998). 
11. Nutbrown, C., Hannon. P. \& Morgan, A., Early Literacy Work with Families: policy, practice and research. London, Thousand Oaks, New Delhi: SAGE Publications, (2005).

12. Nyitrai, Á., A mese, a vers és a képeskönyv szerepe a bölcsődés gyermekek életében és fejlődésében. Bölcsészdoktori értekezés. Kézirat. Szeged: JATE, (1995).

13. Nyitrai, Á., A kompetenciák fejlődése, a fejlődés nyomon követésére és segítésére alkalmas módszerek az óvodában. In: Hét aranyalma. Módszertani gyüjtemény óvodapedagógusoknak. ( pp. 137 $\square$ 162). Budapest: KIM Nemzetpolitikai Államtitkárság, Bethlen Gábor Alapkezelő Zrt., (2012).

14. Nyitrai, Á. \& Darvay, S., A játék és a mese jelenléte a kisgyermekek életében. (pp 73-86). Iskolakultúra, 11, (2013).

15. Podráczky, J., Szülők és iskola - reflexiók és megközelítések. (pp. 16-22). Gyermeknevelés: online tudományos folyóirat, 1, (2013).

16. Réger, Z., Utak a nyelvhez. Nyelvi szocializáció, nyelvi hátrány. Budapest: Akadémiai Kiadó, (1990).

17. Rodriguez, E. T., Tamis-Le-Monda, C. S., Spellmann, M. E., Pan, B. A., Raikes, H., Lugo-Gil, J., \& Luze, G., The formative role of home literacy experiences across the first three years of life in children from low-income families. (pp. 677 $\square$ 694). Journal of Applied Developmental Psychology, 30, (2009).

18. Szinger, V., Kivárás és bontakozó írásbeliség - Hagyomány és újszerüség az óvodai írás-és olvasás elökészítésben. (pp. 70 $\square 85$ ). Könyv és Nevelés, 1, (2007). 